Environmental City 
THIS PAGE INTENTIONALLY LEFT BLANK 


\section{Environmental City}

People, Place, Politics, and the Meaning of Modern Austin

WILLIAM SCOTT SWEARINGEN, JR.

University of Texas Press $\underset{ }{\longrightarrow}$ Austin 


\section{Support for this book comes from an endowment for environmental studies made possible by generous contributions from Richard C. Bartlett, Susan Aspinall Block, and the National Endowment for the Humanities.}

Copyright (C) 2010 by the University of Texas Press

All rights reserved

Printed in the United States of America

First edition, 2010

Requests for permission to reproduce material from this work should be sent to:

Permissions

University of Texas Press

P.O. Box 7819

Austin, TX 78713-7819

www.utexas.edu/utpress/about/bpermission.html

(a) The paper used in this book meets the minimum requirements of ANsI/NIso Z39.481992 (RI997) (Permanence of Paper).

\section{Library of Congress Cataloging-in-Publication Data}

Swearingen, William Scott, I96I-

Environmental city : people, place, politics, and the meaning of modern Austin / William Scott Swearingen, Jr. - Ist ed.

p. cm.

Includes bibliographical references and index. ISBN 978-0-292-7218I-4 (cloth : alk. paper) ISBN 978-0-292-72202-6 (pbk. : alk. paper)

I. City planning-Environmental aspects-Texas-Austin. 2. Land use, UrbanEnvironmental aspects-Texas-Austin. 3. Environmentalism-Texas-Austin. I. Title.

HT243.U62A979 2010

307.I'I6097643I - dc22 
This book is dedicated to all the "ittle old ladies in tennis shoes," who saw what it could look like before the others did;

to Roberta Crenshaw, whose vision, drive, and efforts were so important to what it does look like;

and to Mary Arnold, who is, simply, always there. 
THIS PAGE INTENTIONALLY LEFT BLANK 